\title{
研究報告
}

\section{0 年代に行われた鳴門海峡横断送電線建設に関する風の研究の記録 \\ Record of Study of Wind for Construction of a Transmission Line Crossing the Naruto Straits in 1950s}

\author{
森 征洋* \\ Yukihiro MORI
}

\section{SUMMARY}

Once there was a long span of transmission line crossing the Naruto straits. The transmission line was planed to build in 1950s. An intensive study of wind in the area was made and the design wind speed over the straits was established. The transmission line was built in 1961 and used until 1985. At that time when the line was built, the span of line was the longest in Japan. Throughout the history of wind engineering in Japan the study was the first attempt to establish the design wind speed for large-scale structures such as transmission lines. An outline of this historical study has been shown.

key words: design wind speed, topographic effect, transmission line, strait

\section{1.はじめに}

淡路島と四国の間の鳴門海峡には，かつて図 1 に 示す位置に海峡を横断する長径間の送電線が架設さ れていた。この鳴門海峡横断送電線は, 四国側から淡 路島に電力を送るために 1961 年に建設され, その後 25 年間にわたって運用されていたが, 大鳴門橋の建 設に伴い，1985 年に送電線としての役割を終えた。

この送電線は, 図 2 に示すように, 両岸に建てら れた高さ $100 \mathrm{~m}$ を超える高鉄塔で支えられ，海峡をひ
とまたぎして架設されていた。そのため，径間は $1700 \mathrm{~m}$ になり, 建設当時, 日本最長であった。

鳴門海峡は狭い海域で潮流の変化が激しく, 渦潮 の発生するところとして知られているが，気象状況 も㛜しい。このような場所に長径間の架空送電線を 建設することは日本で最初の試みであり, 設計風速 設定のため, 大規模な風の調査研究が行われた。

この風の調査にはいずれも故人となられた京都大 学名誉教授の滑川忠夫, 石崎潑雄, 光田 寧の先生 


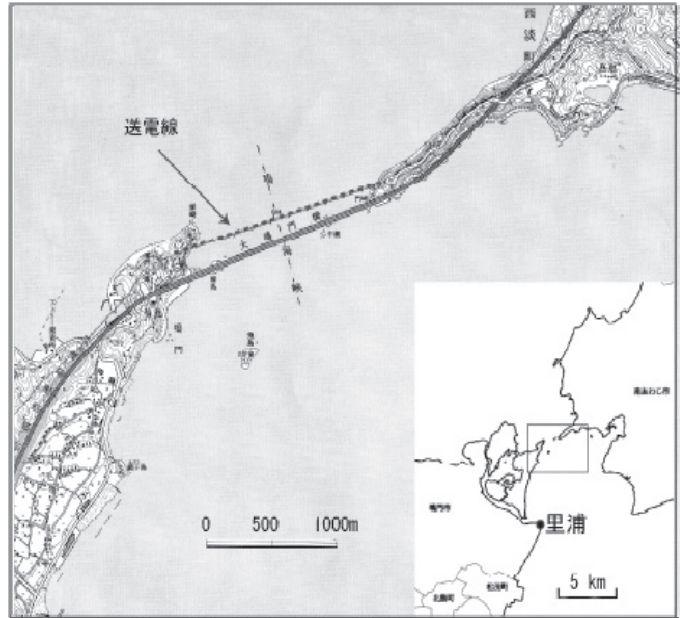

図 1 鳴門海峡周辺の地形図

(国土地理院の地図より作成)

Fig. 1 Map of the Naruto straits

方が関係された。石崎先生は本学会前身の日本風工 学研究会の創設に尽力された方で, 初代会長も務め られた ${ }^{1)}$ 。光田先生は超音波風速計の開発および大気 乱流の研究など気象学の分野で功績のあった方で, 風工学の分野でも活躍された ${ }^{2)}$ 。

この送電線建設に関する研究は, 日本において「風 工学」という言葉がなかった時代 ${ }^{3)}$ に行われたもので, 日本で行われた最初の大規模な風工学に関する調査 と考えられる。筆者は，この調査資料を整理する機 会があったので，日本における風工学の記録として 当時行われた調査・研究について紹介したい。また, その後，個別に行われた地形模型風洞実験，数値シ ミュレーションの結果も合わせて紹介したい。

\section{2. 鳴門海峡横断送電線}

太平洋戦争後の復興期にあった 1950 年代，淡路島 の電力は明石海峡を横断する $20 \mathrm{KV}$ 海底ケーブル 2 回線で関西から供給されていた。しかし，投錨によ る海底ケーブルの切断事故や, 増大する電力需要に 備えるため, 四国側からも電力を供給する計画が持 ち上がった。当時, ゆくゆくは電力に余裕のある四 国の電源地帯から関西方面に電力を供給しようとい う大きな構想もあり，鳴門海峡を横断する $187 \mathrm{KV}$ の 超高圧送電線の建設が計画された。

海峡を横断する送電線は海底ケーブルか架空線の

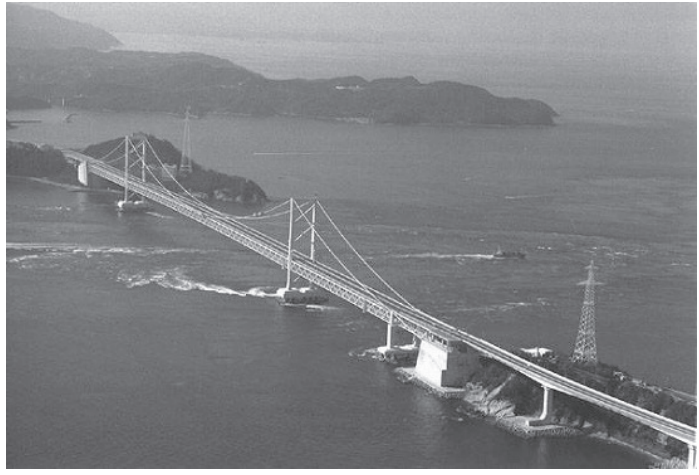

図 2 淡路側から見た大鳴門橋と送電鉄塔 (徳島新聞社提供)

Fig. 2 Ohnaruto bridge and transmission towers view from the Awaji side. The photograph is provided by the Tokushima Shimbun Company.

どちらかを選択することになる。現地調査から鳴門 海峡では海底ケーブルは不可能に近く, 架空線なら ば可能という結論になった。そのため，鳴門海峡を 挟む両方の岬の先端に鉄塔を建て，最狭部分 $1.6 \mathrm{~km}$ の間をひとまたぎする送電線の建設が計画された。

このようなところに架空線を設置する場合，工法 上の問題のみならず，設計に必要な風圧の設定が問 題となる。そのため大規模な風の調査研究が 1956 年

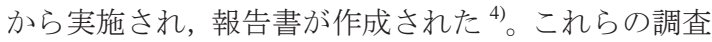
結果に基づいて建設された鳴門海峡横断送電線は 1961 年 9 月 1 日に完成した。

この送電線が完成した直後の 9 月 16 日，第 2 室戸 台風の中心が室戸岬の西方を通り，近畿地方を縦断 した。送電線はこの台風による強風に耐えることが でき，その後も台風などによる被害を受けることな く運用されてきた。しかしながら 1985 年本四連絡橋 大鳴門橋の完成に伴い，橋梁下部に送電線が設置さ れたことにより，鉄塔による送電は終了した。電線と 鉄塔はその後 1997 年に撤去された。

\section{3. 設計風速の設定方法}

鳴門海峡横断送電線は関西電力によって計画が進 められた。しかしながら，気象，地質，建設方法な ど，さまざまな検討課題があったため，京大，阪大 などの学識経験者を含む「鳴門海峡横断送電線建設 調査委員会」が設置された。

送電線建設に当たって検討課題の一つの大きな問 
題は，強風の吹くことが知られている鳴門海峡周辺 の設計風速を決定することであった。そのため，風 の調査が京都大学理学部の滑川忠夫教授, 工学部の 石崎潑雄助教授に委託された。鳴門海峡周辺での風 の調査は当時理学部の大学院生で後に京大防災研究 所の教授として活躍された光田 寧博士が担当した。 送電線の設計にあたって, 関西電力送電課が当初 考えた設計風速の推奨值は永江公式 ${ }^{5)}$ 形式的に適 用するものであった。しかし，この公式を鳴門海峡 のような特殊地形のところにそのまま適用すること が問題とされ，予備的に淡路側岬先端の門崎で 1955 年の台風期に風の観測が行われた。その結果, 門崎 では, 淡路島の洲本測候所や徳島地方気象台におけ る風より 1.5 から 3 倍強い風が吹くことが分かった。 これが地形の縮脈（流れの断面が狭くなる）効果に よるものであるならば鉄塔建設にとって看過できな い問題となる。

地形によって風速がどのように増強されるかは， まず，実情を確かめなければならない。地表近くで の観測は比較的容易であるが，問題とされる高さ $200 \mathrm{~m}$ に及ぶ空域における観測は莫大な費用を投じな いかぎり不可能である。また, 強風時での状況を知 る必要があるので, 測風気球など, 強風に弱い観測 手法は採用できない。

地形による風の増強効果の研究方法として, 今日 では気流の粘性を考慮した 3 次元数值シミュレーシ ヨンが可能であるが，当時は不可能で，また地形模 型を用いた風洞実験による方法は, 費用の点から除 外された。

結局，実行可能な方策として，次の方法が採用さ れた。

（1）海峡部の十数地点において地表近くの風の観測 を行い, 海峡入り口の風と比較することによっ て南東の強風時の各点の地形増強率の実測値を 求める。

（2）水平 2 次元ポテンシャル流を仮定して, 地形を 考慮した理論計算を行い，それにより海峡横断 部の高さ $200 \mathrm{~m}$ 以下の空域における南東風の場 合の理論的地形増強率を算出する。

(3) (2)で得た結果が(1)で得た結果に近づくように 適当な操作を加え，その結果を各点での想定さ れた地形増強率として, 目的の設計風圧の算定 の基礎とする。

\section{4. 現地観測の結果}

鳴門海峡周辺の 10 数地点で風の観測が 1956 年か ら 1959 年まで, おもに台風期に行われた。観測に用 いられた測器や設置高度などは表 1 に, 観測地点の 配置は図 3 に示す。海峡入口の地点 1 (里浦) の位置 は図 1 に示す。風速の観測にはすべての地点で 4 杯 ロビンソン風速計（気象庁検定済）が用いられた。 この風速計は風程接点を持ち，風程パルスが積算記 録器により記録された。地点 5,6 では風車型風向 風速計も用いられ, 瞬間風速・風向の観測も行われ た。風向の観測は地点 1 を含むいくつかの地点で矢 羽根型風向計により行われた。風向計からの出力は, 自記器により連続的に記録された。淡路側岬先端近 くでは，尾根上（地点 9）と尾根より下がった階段 状平地（地点 8 ）に観測点が設けられた。この地点 では $5 \mathrm{~m}$ と $10 \mathrm{~m} の 2$ 高度で観測が行われ， $5 \mathrm{~m}$ の高度 ではロビンソン風速計のほかユニバーサル風速計 （ダインス式風速計で，風向も測定できるようにし たもの）が用いられた。

表 1 観測地点と測器および設置高度。 $\mathrm{R}$ : ロビンソ ン風速計, $\mathrm{V}$ : 矢羽根型風向計, $\mathrm{K}$ ：風車型風向風 速計 (コーシンベーン), $\mathrm{U}$ ：ユニバーサル風速計

Table 1 Observation sites and instruments

\begin{tabular}{|r|l|l|r|r|}
\hline $\begin{array}{l}\text { 地点 } \\
\text { 番号 }\end{array}$ & 地点名 & 測器 & $\begin{array}{l}\text { 地面 } \\
\text { 高度 } \\
\text { (m) }\end{array}$ & $\begin{array}{l}\text { 風速計 } \\
\text { 地上高 } \\
(\mathrm{m})\end{array}$ \\
\hline 1 & 里浦 & $\mathrm{R} \mathrm{V}$ & 10 & 5 \\
\hline 2 & 公園バス停 & $\mathrm{R}$ & 5 & 5 \\
\hline 3 & 配電柱上 & $\mathrm{R}$ & 54 & 5 \\
\hline 4 & つつじ丘 & $\mathrm{R} \mathrm{V}$ & 99 & 10 \\
\hline 5 & 孫崎灯台 & $\mathrm{R} \mathrm{V} \mathrm{K}$ & 36 & 10 \\
\hline 6 & 飛島 & $\mathrm{R} \quad \mathrm{K}$ & 25 & 3 \\
\hline 7 & 裸島 & $\mathrm{R}$ & 19 & 5 \\
\hline \multirow{2}{*}{8} & 鳥居上(B) & $\mathrm{R}$ & 20 & 10 \\
\cline { 2 - 5 } & 鳥居下(A) & $\mathrm{R} \mathrm{U}$ & 20 & 5 \\
\hline 9 & やぐら & $\mathrm{R} \mathrm{V}$ & 50 & 10 \\
\hline 10 & 駐車場 & $\mathrm{R}$ & 42 & 5 \\
\hline 11 & ガレ & $\mathrm{R}$ & 75 & 5 \\
\hline 12 & 篠山 & $\mathrm{R} \mathrm{V}$ & 92 & 5 \\
\hline 13 & 行者灯台跡 & $\mathrm{R}$ & 51 & 8 \\
\hline
\end{tabular}


台風期における観測から，鳴門海峡で強風が生ず るのは，海峡に直角よりの方向から風が吹き込む場 合で, 最大風速は南東風または北西風の場合に発現 すると考えられた。さらに，両岸から突き出した岬 の間の海峡上の風を考える場合, 南東風と, 北西風 とでは，左右は逆になるが，地形の影響は同じと考 えられるので, 設計風速は南西風の場合について検 討された。

風の解析には風向，風速ともに 1 時間ごとの 1 時 間平均值が用いられた。風速は, 風程の 1 時間積算 值から求められた。風向は 1 時間の風向変動の連続 記録より平均值が読み取られた。台風接近時に観測 された強風で, 南西方向から吹き込む場合について, 地点 1 (里浦) の風速に対する各観測点の同時風速 比を求め, その平均值を地形増強率とした。観測地 点によって風速計の高度が異なっているので, $10 \mathrm{~m}$ の高度に換算する補正が施された。

このようにして求められた平均的な地形増強率と, 台風時に観測された風速分布の例を図 3 に示す。岬 の先端や稜線上の地点で風速が増強され, 地点 1 に 比べて約 2 倍の強さの風が吹いていることが分かる。 さらに，詳しく見ると淡路側岬の先端附近では，稜 線上(地点 9)より低い位置にある地点 8 で風速が大き く, しかも $10 \mathrm{~m}$ 高度（8B）より高度の低い $5 \mathrm{~m}$ 高度 （8A）の方が大きくなる傾向がある。これは水平方 向に岬を迂回する流れによるものと考えられた。

最大瞬間風速と平均風速の観測から突風率が調べ られた。実測值から突風率は高さ $10 \mathrm{~m}$ では 1.4 と設 定され, 高さによる変化は, Sherlock の実験式 ${ }^{7)} よ$ るものとして, 設計用の最大瞬間風速の予測值が決 定された。

瞬間風向・風速の観測を行った地点の記録から, 副産物として海峡上に小旋風の発生することが明ら かにされた ${ }^{8)}$ 。小旋風は一般風が強風の場合も弱風の 場合も発生し, 大多数は反時計回りの回転を示して いた。その内域の半径は $0.5 \sim 1.5 \mathrm{~km}$, 最大旋回風速 は 6 13m/s 程度で, 6〜 30km/h の移動速度で海峡に 沿って北向き，または南向きに移動していた。

\section{5. 設計風速の設定}

現地観測から風の地形による増強効果が調べられ たので,この結果に基づいて設計風速の検討が行わ れた。

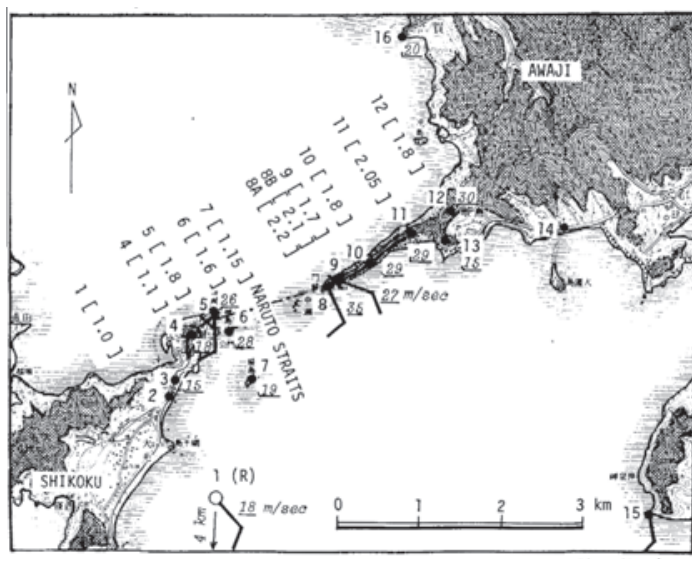

図 3 台風 6710 号（1967 年 9 月 7 日 1600 JST) のときに観測された鳴門海峡における風速分布 (実測值) ${ }^{6)}$ 。地点番号に付した $[$ ]内の数值は地 形増強率。

Fig. 3 Map of the Naruto straits, which shows the distribution of the observing stations. The arrows and numbers in italic show the wind distributions in the straits observed in the typhoon 6710 at 1600 JST Sept. 7, 1967. The bold figures in the brackets are the intensification factors determined by the observational results of southeasterly storm winds.

まず，この地域の最大風速を設定する。風速の再 現期間が，徳島地方気象台の 28 年間の観測データを 用いて Jenkinson の方法 ${ }^{9}$ により検討された。その結 果, 最大風速を $40 \mathrm{~m} / \mathrm{s}$ とすると, 100 年以上の再現期 間を持つことが分かった。そこで，この風速を鳴門 海峡に吹き込む風の最大值とした。

次に，このような風が鳴門海峡に吹き込むとき， 岬の周辺および海峡上における風の予測值を求める。 現地観測の結果から，岬近くの風は推定できるが， 海峡上の風については分からない。そこで光田は理 論計算によって海峡上の風を予測することを考えた。

まず，海峡に流入する wind profile を設定する。当 時, 海上については知られていなかったので, 海岸 近くの草地で観測された, 次の Deacon の実験式 ${ }^{10)}$ が採用された。

$$
v(z)=v_{10}\left(\frac{z}{10}\right)^{0.16}
$$


ここで， $\mathrm{v}(\mathrm{z}) ， \mathrm{v}_{10}$ は，それぞれ高さ $\mathrm{z}$ および $10 \mathrm{~m}$ に おける風速である。この式のべき乗数は経験的に与 えられるもので, 現在では, 海上の風については Davenport $^{11)}$ による 0.1 の值が用いられる。乗数を 0.16 として地表近くの風から上空の風を推定する場合, 予測值は大きくなるが，結果としては安全側に予測 することになる。

このような鉛直分布を持った気流が岬によってよ゙ のように変形をされるか, 光田は実地形の周りの風 を数值計算によって求めることを試みた。当時, 摩 擦を考慮しないポテンシャル流を仮定しても 3 次元 問題として解くことは難しかった。光田は, 海峡に 流入する空気が海峡の狭くなったところで岬という 障壁に衝突する際，岬を迂回する気流と岬を越える 気流が生ずることに着目し，その割合を仮定するこ とにより, 水平 2 次元問題として解くことを考えた。 境界条件には実地形を用いて, relaxation method ${ }^{12)}$ で ポアソン方程式を解き, 結果を合成することにより 風の分布を求めた。

岬を越える気流と迂回する気流の割合を幾通りか 変えて計算を行った結果, この割合を半々として求 めた計算結果に摩擦による減衰効果を考慮すると実 測結果との整合性がよいこと分かった。そこで，こ の割合で計算を行った結果を予測值とした(図 4 )。

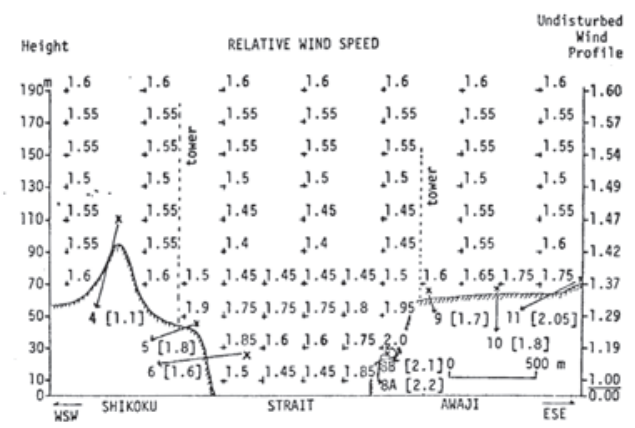

図 4 鳴門海峡断面における南東風の場合の風の 予測值と地表付近の実測值（カギ括弧）。地形の 影響を受けないところの高さ $10 \mathrm{~m}$ の風速を 1 と して相対比で表している。

Fig. 4 Estimated and observed (in the bracket) relative wind speeds (relative to the reference wind at a height of $10 \mathrm{~m}$ ) in the cross section of the Naruto straits in the case of southeasterly wind.

この図では海峡断面の風速分布を風上海上 $10 \mathrm{~m}$ の
高さの風速を 1 として相対比で表している。海峡上 の風には, 高度に伴う風速の増加だけではなく, 地 形による増強効果が含まれている。この予測值に基 づいて提案された設計風速推奨值（瞬間風速）には 発生の可能性のある小旋風の影響も加算された。

光田が用いた数值計算の手法は, 1970 年代後半に 登場した Dickerson ${ }^{13)}$ や Sherman ${ }^{14)}$ による変分法を用 いた複雑地形上の気流計算そのものであり,これら の研究に先立つことおよそ 20 年前にして, 計算尺で 流れポテンシャルを解き, 複雑地形周囲の気流計算 を行った光田の先進性には, 今更ながら驚かされる。

\section{6. 送電線の敷設}

風の現地観測と海峡上の風の予測值より, 送電線 の設計風速は, 上空の風について, 平均風速 $75 \mathrm{~m} / \mathrm{s}$, 最大瞬間風速 105m/s（ただし，電線に対しては平均 風速 $65 \mathrm{~m} / \mathrm{s}$ ) という值が推奨された。

風の乱れの性質から，構造物の受圧面が大きくな れば最大瞬間風速は構造物全面に同時には作用しな いと考えられる。したがって構造物が大きくなれば, 対象とする構造部分の大きさに応じて設計用風圧度 を減少させても差し支えないことになる。しかしな がらこの減少率については当時知られていなかった。

石崎は鳴門の孫崎灯台およびその付近に歪計型風 圧計を 3 台配置し, 1956 年度, 1958 年度の台風期に オッシログラフ記録器で瞬間風圧の同時測定を行っ た。この結果に基づいて設計用風圧を受圧面の大き さに応じて低減できる実験式を提案した。

これらの結果に基づいて送電線の設計が進められ た。送電線を鳴門海峡の上に敷設する工事は住友電 工により 1961 年 6 月に行われた。この工事は, 気球 を使って送電線を渡すという世界でも初めての試み であり，同社の歴史において戦後からの復興を示す 一時代を画した年に行われた出来事の一つとして記 録されている ${ }^{15)}$

電線架設工事は淡路側の門崎に建てられた鉄塔か ら直径 $9 \mathrm{~mm}$ のメッセンジャーワイヤを曳いた船が 対岸に向かって出発することにより始められた。ア ドバルーン業者より集めた 77 個の気球に釣り下げら れたワイヤが鳴門海峡の上に浮かび，2 時間後には 鳴門側の孫崎に到着して工事は無事成功した。世界 で 3 番目という長さで注目された海峡横断送電線の 敷設工事だったが，ヘリコプターを使用せず，気球 
を使ったということはまさに日本的と, 週刊誌に「風 船爆弾以来の着想」として写真(図 5)付きで紹介され た ${ }^{16)}$ 。なお，1997 年に行われた送電線撤去工事では ヘリコプターが用いられた ${ }^{17)}$ 。

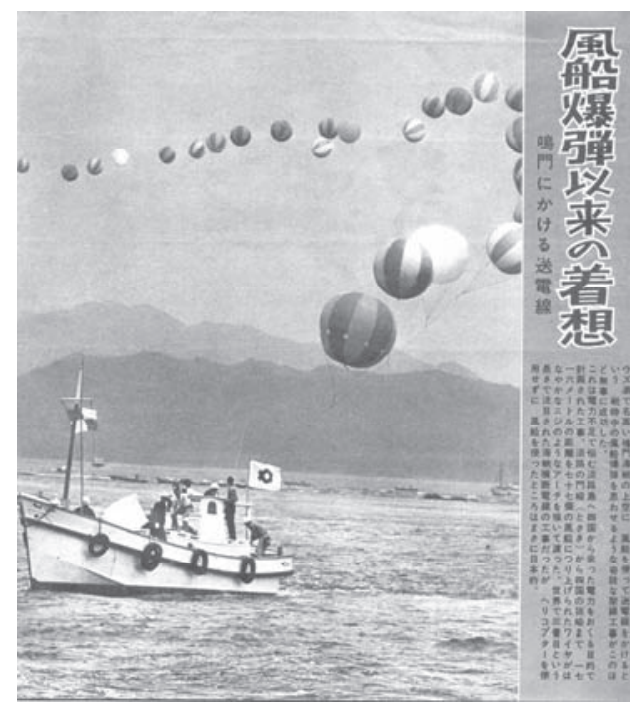

図 5 風船で送電線をかける鳴門海峡

(週刊新潮 1961 年, 279 号, 道 正太郎撮影)

Fig. 5 Wire stringing over the Naruto straits with the use of balloons

この送電線による四国から淡路島への送電は 1961 年 9 月から $66 \mathrm{KV}$ で始まり, 1972年 11 月からは $187 \mathrm{KV}$ で運用されるようになった。この結果，淡路島のお よそ南半分の電力は四国からの送電でまかなわれる ようになった。

\section{7.鉄塔における風と気温の観測}

送電線建設後，設計風速算定の妥当性を検証する ために，四国側鉄塔（地面海抜 $34 \mathrm{~m}$ ）では 5 高度（地 上 $21,47,74,100,146 \mathrm{~m})$ で風の観測, 淡路側鉄 塔（地面海抜 42m）では 4 高度（地上 16，37，69, $115 \mathrm{~m}$ ）で風と気温の観測が行われた ${ }^{6)}$ 。

風の観測には風車型風向風速計（光進電機）が用 いられた。風向風速計 9 台のらち 4 台は風程接点の み内蔵された。風程パルスは電接計数器で積算值が 記録され，瞬間風速・風向は紙に連続的に記録され た。風向風速計の動特性があらかじめ京大防災研究 所の風洞で調べられ, 風速計の距離定数 $6.2 \mathrm{~m}$, 風向 計の固有波長 $13.2 \mathrm{~m}$ ，減衰比 0.18 であった。この結
果から,この風向風速計は $10 \mathrm{~m} / \mathrm{s}$ 程度以上も風が吹い ていれば，数秒周期の変動までは十分追随すると見 なされた。

平均風速は，風程パルスの積算記録から 1 時間ご とに 1 時間平均值が求められた。最大瞬間風速は 1 時間ごとに，その間の最大值が目で読み取られ，平 均風向も 1 時間ごとに 1 時間のトレースより目で読 み取られた。平均風速, 平均風向, 瞬間風速のほか に, 気温の観測も行われ，大気の安定度も調べられ た。

観測は送電線が完成した 1961 年 9 月 1 日の直後か ら始められる予定であったが，この月の中旬に襲来 した第 2 室戸台風時には測器の準備が間に合わず, 観測は 10 月から始められ, 1965 年まで続けられた。 4 年間の観測期間中に強烈な台風による強風の観測 には恵まれず，設計風速の $1 / 3$ 程度の強風の観測 データしか得られなかったが，海峡に突き出た岬の 先端における wind profile の特徵が調べられた。岬の 先端では, 大気の安定度が安定な場合, 気流は岬の 稜線を越えずに，岬を迁回し，大気の安定度が中立 ないしは不安定になると, 稜線を越える傾向にある ことが認められた ${ }^{6)}$

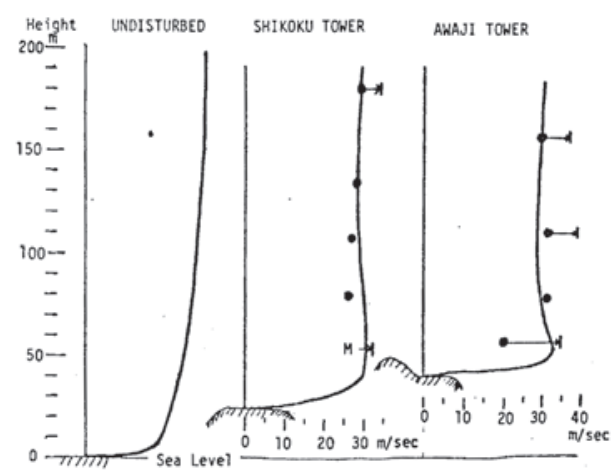

図 6 鉄塔における風の予測值と実測值 ${ }^{6)}$ 。黒 丸は台風 6419 号 (1964 年 8 月 24 日, $1700 \mathrm{JST}$ ) における南西風のときに観測された平均風 速，矢印は最大瞬間風速。

Fig. 6 Estimated and observed wind profiles at the transmission towers. The black dot shows mean wind speed and the arrow means peak gust observed in the Typhoon 6414, at 1700 JST Aug. 24, 1964 when wind blows from southeast. 
鉄塔における風の実測值と予測值との関係を図 6 に示す。Wind profile は上空で一致させている。淡路 側の地表近くで実測值と予測值との間に大きな差が 見られるが，それより高いところでは wind profile は 一致している。瞬間風速の観測が行われていた 5 カ 所での最大瞬間風速の結果も示す。また，鉄塔にお いて南よりの強風の場合に観測された突風率の平均 值と設計用風速算定のために用いた突風率の対比を 表 2 に示す。低い高度では実測值の方が大きいが, 高い高度ではほぼ一致している。

表 2 南よりの風の場合の突風率

Table 2 Gust factors for southerly wind

\begin{tabular}{lccccc} 
鉄塔 & \multicolumn{3}{c}{ 淡路側(34m) } & \multicolumn{3}{c}{ 四国(鳴門)側(42m) } \\
\hline 地上高 & $21 \mathrm{~m}$ & $146 \mathrm{~m}$ & $16 \mathrm{~m}$ & $69 \mathrm{~m}$ & $115 \mathrm{~m}$ \\
\hline 実測值 & 1.57 & 1.18 & 1.55 & 1.13 & 1.14 \\
設計用 & 1.34 & 1.18 & 1.37 & 1.24 & 1.20 \\
\hline
\end{tabular}

\section{8. その後の研究}

鳴門海峡の風については, 後に地形模型風洞実験 と 3 次元数值シミュレーションが行われた。

風洞実験は本州四国連絡橋大鳴門橋の建設に関係

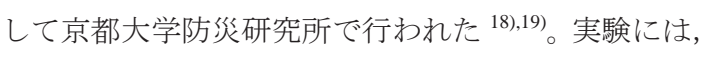
図 7 に示すように, 鳴門海峡を囲む, 水平方向の縮 率が 1/12000, $1 / 4000$ の地形模型と, 淡路側岬の部分 を拡大した縮率 $1 / 2000$ の 3 つ地形模型が用いられ た。1/12,000 模型については, 実験の都合で, 鉛直方 向の縮率を 1/4000 とし，3 倍に拡大された。実験は 海峡に吹き込む南南西の風について行われた。

数值シミュレーションは吉田により CHAM 社の 3 次元流体解析ソフトウェア PHOENICS を用いて行わ れた ${ }^{20)}$ 。格子間隔は水平方向に $50 \mathrm{~m} \times 50 \mathrm{~m}$, 鉛直方向 に $5 \mathrm{~m}$ とし, 風上の風速プロファイルは(1)式で, 心゙き 乗数を 0.1 として与えた。

これらの結果と, 現地観測の結果とを比較してみ る。風洞実験では, 模型の縮率による違いは小さか ったので $1 / 4000$ 模型の結果を用いる。地形の影響を 受けない海上 $10 \mathrm{~m}$ 高度の風に対する風速比で表した 地形増強率について, 比較を図 8 に示寸。風洞実験 による地形増強率は全体に小さく, 局所的な地形に よる風速の増強は再現されていない。

数值シミュレーションの結果について見ると, 岬 の先端の地点 5 (孫崎灯台), 地点 $8 \mathrm{~B}$ (鳥居上) にお
いては，実測では 1.8 および 2.1 であるが，計算值で は両地点とも 1.5 で実測によるものより小さい。稜線

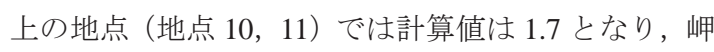
の先端より大きく, 実測の値に近くなる。一方, 地

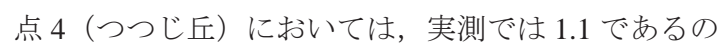
に対して, 計算値では 1.7 と大きい。この地点は岡の 最頂部で地面高度が高いところにあるにもかかわら ず，他の地点より小さい。実測値は局所的な地形の 影響も受けているものと考えられる。

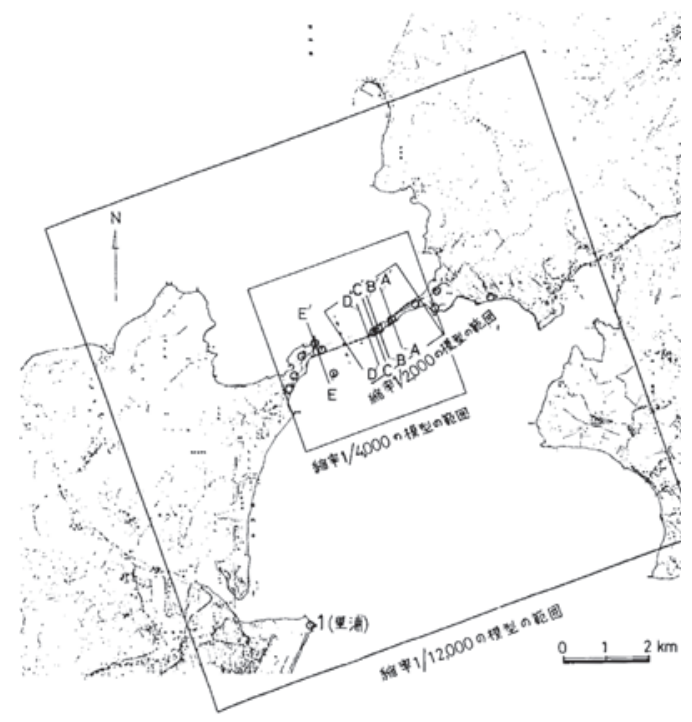

図 7 地形模型作成範囲および実測地点（白丸）

Fig. 7 Coverage areas for topographic models and the observing stations

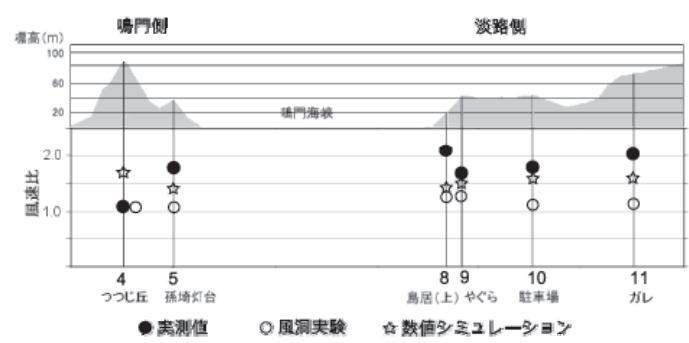

図 8 鳴門海峡における南東風の場合の地形増強 率（風上海上 $10 \mathrm{~m}$ 高度の風に対する相対比）

Fig. 8 Topographic intensification factors of wind speed in the case of southeasterly wind in the Naruto straits 
風洞実験では，地表近くの実測においてみられる ような地形による風速の大きな増強は再現されなか った。しかしながら, 図 9 に示したように, 淡路側 送電鉄塔における wind profile の実測值と風洞実験の 結果とは地表近くを除けばよく一致していたので, 風洞実験は上空の風の性質についてはかなりよく再 現していると考えられる。

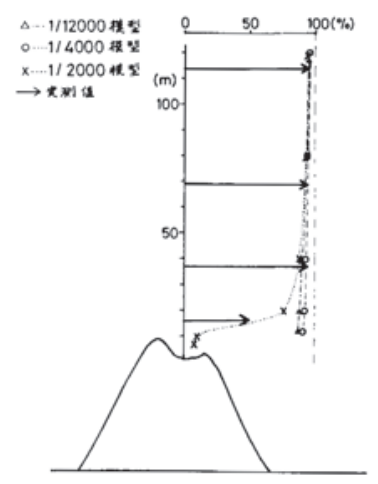

図 9 淡路側鉄塔における wind profile $の$ 実測值と 風洞実験の結果との比較 ${ }^{8)}$

Fig. 9 Comparison of wind profiles obtained from the wind tunnel experiment and observed ones at the Awaji tower

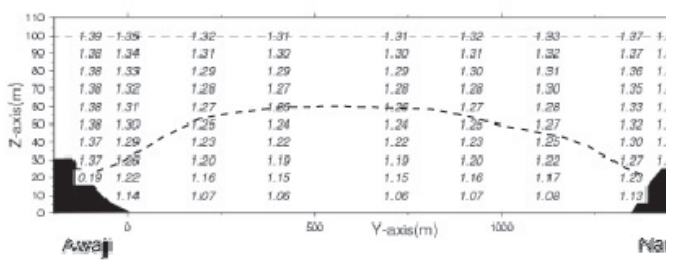

図 10 鳴門海峡における南東風の場合の相対風 速の分布 ${ }^{20)}$. 風上海上 $10 \mathrm{~m}$ の風速を 1 としたと きの相対比で表す.太鎖線は 1.26 (風上海上 $100 \mathrm{~m}$ の風に相当）

Fig. 10 Relative wind speeds estimated from the numerical experiment in the case of southeasterly wind in the cross section of the Naruto straits

吉田による, 図 4 に対応する 3 次元シミュレーシ ヨン結果を図 10 に示す。北西側から鳴門海峡を見る 断面で表しているので, 図 4 とは, 淡路側, 四国側 が反対になっている。海峡上の風は全体的に強くな る。例えば，与えられた wind profile では，風上海上
$100 \mathrm{~m}$ 高度の風速比は 1.26 となるが，この風速比にな る高さは海峡中央部では高度 $60 \mathrm{~m}$ まで下がり, 両岬 に近づくほどさらに低くなる。海面近くの風の増強 の程度は, 海峡中央部の $10 \mathrm{~m}$ の高さで 1.06 となって おり，図 4 の場合と大きく異なる。この違いは図 4 の場合, 2 次元ポテンシャル流で計算を行っている ことと関係していると思われる。

図 10 の相対風速は図 4 の場合に比べ全体的に小さ い。この原因の一つは, 図 4 では風上における wind profile のべき乗数を 0.16 としているので, 基準とし た $10 \mathrm{~m}$ 高度の風速に対する相対比で表すと, べき乗 数を 0.1 とする場合に比べて上空の風速比は大きく なる。

海峡上では中央部よりも陸に近いところで風速が 最も大きくなるという特徵は，明石海峡や関門海峡 などにおける現地観測や風洞実験における結果と一 致している ${ }^{21)}$ 。

\section{9.おわりに}

複雑な地形上の構造物に対する風の影響を考える 場合, 地形による風の変形が問題になる。鳴門海峡 横断送電線建設に関しては, 海峡という特殊地形上 での風の特性が問題とされた。この建設計画が始ま った 1950 年代において, 風の調査は, 自記紙に記録 されたトレースを読み取り数值化するという大変労 力を要するものであった。コンピュータが普及する 以前の時代に困難な現地観測と手計算による数值解 析とを結合させることにより設計風速が決定され， 長径間の送電線が建設された。

その後, 鳴門海峡の風の特性について, 地形模型 風洞実験と 3 次元数值シミュレーションによる研究 が行われた。風洞実験による結果と現地観測の結果 とを比較すると, 鉄塔による wind profile は地表近く を除くとよく一致していたが，局所的な地形による 風速の増強は再現されなかった。

3 次元数值シミュレーションの結果を現地観測の 結果と比較すると, 全体として地形による風速の増 強は再現されているが, 地表近くの地形による風速 増強の程度は実測より小さく, 局所的な地形による 風速増強を量的に再現には課題があることを示して いた。 
謝辞

この報告を作成するに当たり, 京都大学防災研究 所石川裕彦教授より有益なご助言をいただいたこと に感謝します。また, 光田 寧先生が保管していた 鳴門海峡横断送電線建設に関係する資料を借用させ ていただいた光田節子様に感謝します。

\section{参考文献}

1) 石崎 潑雄, 伊藤 学, 加藤 勉, 白石 成人, 「日 本風工学の発足にあたって」, 日本風工学会研究 会会報, Vol. 1976, No. 1, p. 1, (1976)

2) 林 泰一,「光田 寧先生のご逝去を悼んで」, 日 本風工会誌, 第 79 号, pp. 219-220, (1999)

3) 石崎 潑雄, 「風工学以前」, 日本風工学会誌, Vol. 1985, No. 25, pp. 1-3, (1985)

4) 関西電力株式会社送電部工務課, 「設計風圧算定 の目的で施工した鳴門海峡に於ける暴風観測報 告」，第 5 報(終末報告), (1960)

5) 永江 篤, 「風圧」, 電気学会雑誌, 第 58 巻, 第 584 号, (1937)

6) Mitsuta, Y., "Characteristics of airflow over the barriers in the storm”, Proceeding the 3rd International Conference on Wind Effects on Buildings and Structures, Saikan Shuppan Co., 4, pp. 1-12, (1971)

7) Sherlock, R. H., "Variation of wind velocity and gusts with height”, Proc. Amer. Soc. Civ. Eng., Vol. 78, (Separate No.126), pp.1-16, (1952)

8) 光田 寧, 「鳴門海峡附近の小旋風について」, 海 と空, 第 2 号, pp. 67-71, (1962)

9) Jenkinson, A. F., "The frequency distribution annual maximum (or minimum) values of meteorological elements”, Quarterly Journal of Royal Meteorological Society, Vol. 81, pp. 158-171, (1955)
10) Deacon, E. L., "Gust variation with height up to 150m”, Quarterly Journal of Royal Meteorological Society, Vol. 81, pp. 562-573, (1955)

11) Davenport, A. G., "The dependence of wind loads on meteorological parameters”, Wind Effects on Buildings and Structures, Proceedings, Vol. 1, University of Toronto Press, pp. 19-81, (1967)

12) Southwell, R.V., "Relaxation Methods in Theoretical Physics”, Oxford, (1946)

13) Dickerson, M. H., "MASCON-A mass-consistent atmospheric flux model for regions with complex terrain”, Journal of Applied Meteorology, 17, pp. 241-253, (1978)

14) Sherman, C. A., "A mass-consistent model for wind fields over complex terrain”, Journal of Applied Meteorology, 17, pp. 312-319, (1978)

15）長谷川誠二, 松尾 総子, 山口 敦,「リーディン グ・カンパニーシリーズ 住友電気工業」, 出版 文化社, (2008)

16) 週刊新潮,「風船爆弾以来の着想一鳴門にかける 送電線」, 通巻 279 号, pp. 123-125, 新潮社, (1961)

17) 鎌野 拓也, 「架橋に合わせて変わる送電設備」, 電気学会, 第 117 巻, 第 11 号, p. 781, (1997)

18）京都大学防災研究所耐風構造部門，「鳴門海峡に 関する地形模型風洞実験成果報告書」, (1973)

19）光田 寧, 森 征洋, 「鳴門海峡付近の風の特定の 実験的研究」, 構造物の耐風性に関寸る第 3 回シ ンポジウム論文集，pp. 45-72, (1974)

20) 吉田 真純，「地形による風の変形に関する研究 一女木島と鳴門海峡における強風の数值シミュ レーションー」, 香川大学大学院教育学研究科修 士論文, (2005)

21）塩谷 正雄，「強風の性質一構造物の耐風設計に 関連して一」, 開発社, (1992) 